\title{
Unsatisfactory microbiological aspects of UHT goat milk, soymilk and dairy beverage of goat milk and soy protein: A public health issue
}

\author{
Taís Ramalho dos ANJOS ${ }^{1}$, Valéria Quintana CAVICCHIOLI², Joyce Aparecida Santos LIMA ${ }^{1}$ (i), \\ Alenia Naliato VASCONCELLOS ${ }^{3}$, Andréia Cristina Nakashima VAZ ${ }^{3}$, Gabriel Augusto Marques ROSSI ${ }^{1}$, \\ Maria Emilene Martino CAMPOS-GALVÃO², Svetoslav Dimitrov TODOROV ${ }^{2}$, Luis Antonio MATHIAS ${ }^{1}$, \\ Rubén Pablo SCHOCKEN-ITURRINO ${ }^{1}$, Luís Augusto NERO ${ }^{2}$, Ana Maria Centola VIDAL ${ }^{3 *}$
}

\begin{abstract}
Spore forming bacteria can play an important role in food quality and safety as spoilage and pathogenic microorganisms due to resistance to heat-treatment. However, there are limited number of studies focused on evaluate the microbiological quality and the occurrence of these bacteria in UHT goat milk, soymilk and dairy beverage of goat milk and soy protein. In this context, 75 samples of these beverages were evaluated regarding heterotrophic mesophilic microorganisms by conventional plate count and selective methods to detect microorganisms from Bacillus cereus group and Clostridium perfringens. Population counts greater than $10^{4} \mathrm{CFU} \cdot \mathrm{ml}^{-1}$ of heterotrophic mesophilic microorganisms were observed in $80 \%$ of the lots of goat milk and $100 \%$ of the lots of soymilk and dairy beverage of goat milk and soy protein. The presence of bacteria belonging to B. cereus group was observed in $16 \%, 52 \%$ and $44 \%$ of goat milk, soymilk and dairy beverage of goat milk and soy protein, respectively. C. perfringens was isolated from $8 \%$ samples of UHT soymilk. The frequency of genes $h b l A, h b l B, h b l C$, nheA, nheB, nheC in 29 isolates obtained from these products was $62 \%, 48.2 \%, 96.5 \%, 79.3 \%, 68.9 \%$ and $79.3 \%$, respectively. The microbiological quality of the evaluated products was unsatisfactory.
\end{abstract}

Keywords: foodborne pathogens; microbiology; PCR; spores.

Practical Application: Presence of spore-forming bacteria in UHT products whose microbiological quality is unknown.

\section{Introduction}

Spore forming microorganisms can be present in dairy products, and they are usually associated with spoilage of milk and dairy products, especially those processed under high temperature, including powder milk, canned dairy products, goat milk, cow milk and some cheeses (Eijlander et al., 2019; Jindal \& Anand, 2018; Pinto et al., 2018; Oliveira et al., 2016c; Vidal et al., 2016; Reindl et al., 2014). These microorganisms can also be isolated in non-dairy products, such as soymilk, that has been increasingly consumed by lactose-intolerant people and children's formulas. For this reason, and based on the beneficial aspects these products promote, several consumers are including these alternatives on their regular diet (Rezende et al., 2015; Kwok et al., 2002).

Goat milk, for example, is considered an option for several consumers, due to low alergenic properties, characterizing it as an alternative to substitute cow milk (Mituniewicz-Małek et al., 2019; Clark \& Mora García, 2017; Kuchtík et al., 2015). The goat milk has high dietary value and nutritional quality, and it has been highly recommended to feed children, adults and elderly people suffering from cow milk allergies, and I is also being used as a substitute for dairy products by consumers with dietary restrictions (Fangmeier et al., 2019; Mituniewicz-Małek et al., 2019; Pradeep Prasanna \& Charalampopoulos, 2019; Beltrán et al., 2018; Nakajima et al., 2010). In this sense, goat milk products have high added values with a growing marketing demand (Mituniewicz-Małek et al., 2019; Fonseca et al., 2013).

Another option for lactose intolerants and people suffering from milk allergy are soymilk and soy beverages, due to their higher digestibility and low fat content compared to cow milk. However, some of these products are not subjected to efficient thermal treatments, capable to eliminate spores (Karaçali et al., 2018; Blum et al., 2016).

Thermal treatments are employed to milk and dairy products in order to reduce or to eliminate vegetative cells, however, spore forming bacteria are heat resistant and they may remain stable after pasteurization or even Ultra Hight Temperature (UHT) processes, being classified as "highly heat resistant spores" HHRS (Eijlander et al., 2019; Jindal \& Anand, 2018; Pinto et al., 2018; Kmiha, et al. 2017; Schoken-Iturrino et al., 1996). Thermal resistance is also related to several factors, such as strain type, growth temperature, age of the spores and environmental features (Oliveira et al., 2016c). 
Ohmic heating has been considered an alternative to eliminate spores in milk, by using temperatures around $105^{\circ} \mathrm{C}$ for 60 seconds, resulting in an effective way to protect food products due to structural damages caused to the spore structure (Ryang et al., 2016). Promote a rapid and homogeneous heating guaranteeing a greater amount of nutrients and sensory attributes to the producer (Ferreira et al., 2019a; Ferreira et al., 2019b; Cappato et al., 2018a; Cappato et al., 2018b).

The main species of spore forming bacteria considered as microbiological risks to food safe and quality are Bacillus spp. and Clostridium perfringens, and these microorganisms are usually present in milk, once they are widespread in soil, silage, digestive tract of animals and grains as soy, possibly contaminating soy products (Eijlander et al., 2019; Garcia et al., 2018; Oliveira et al., 2018d; Oliveira et al., 2016c; Ryang et al., 2016; Quigley et al. 2013). Then, if the raw material is obtained in poor hygienic conditions and if the thermal treatment is ineffective, there are chances to find spore forming bacteria contaminating end products (Pinto et al., 2018; Schoken-Iturrino et al., 1996).

The microbiological control of these products is required to provide safe food, improve their shelf life and avoid the transmission of foodborne diseases, mainly to susceptible individuals. However, there are few studies available in the literature focused on evaluating the microbiological quality of goat milk, soymilk and dairy beverage of goat milk and soy protein.

Thus, this study focused on count populations of heterotrophic mesophilic microorganisms, the bacteria belonging to Bacillus cereus group and C. perfringens in UHT treated goat milk, soymilk and dairy beverage based on combination of goat milk and soy proteins, and posteriorly verify the diarrheagenic potential of the isolates belonging to $B$. cereus group.

\section{Materials and methods}

\subsection{Sample collection and microbiological analyses}

A set of 75 samples of goat milk, soymilk and dairy beverage of goat milk and soy protein from different brands were obtained from supermarkets located in the state of São Paulo, Brazil. Selection criteria used were UHT processing, collecting 5 different lots, and 5 samples per lot, in a total of 25 samples of each kind of product. Goat milk from the same brand, soymilk from different 3 brands, and dairy beverage of goat milk and soy protein from the same brand were collected. The convenience sampling had the purpose to obtain a representative sample of UHT products commercially available in Brazil. Samples were collected from April to December 2015, and they were incubated at $37^{\circ} \mathrm{C}$ during seven days (Brasil, 2001). Posteriorly serial dilutions were prepared on $0.1 \%$ peptone water and plated on recommended agar mediums. To perform heterotrophic mesophilic microorganisms counts, samples were seeded on Plate Count Agar (Difco, Detroit, MI, USA) and incubated at $35^{\circ} \mathrm{C}$ (American Public Health Association, 2001).

To evaluate the presence of vegetative cells of bacteria belonging to the $B$. cereus group the samples were incubated at $30^{\circ} \mathrm{C}$ for $24-30$ hours (Stadhouders, 1992). For the selective plating, an aliquot of $0.1 \mathrm{ml}$ of selective enrichment culture was inoculated in Petri dishes containing mannitol egg yolk polymyxin $\mathrm{B}$ agar (MYP) (Mossel et al., 1967) and incubated at $30^{\circ} \mathrm{C}$ for 18-40 hours. Characteristic colonies described by Mossel et al. (1967) and Stadhouders (1992) and gram-positive bacilli were considered as possible representatives of $B$. cereus group.

To evaluate the presence vegetative cells or spores from C. perfringens, the samples were seeded on plates containing tryptose-sulfite-cycloserine agar (TSC) with egg yolk with a TSC overlay, incubated $35^{\circ} \mathrm{C}$ during two days under anaerobic conditions (American Public Health Association, 2001). Gram staining, catalase test, lactose fermentation, indol, motility, gelatinase test, nitrate reduction and C. perfringens confirmation were also performed (American Public Health Association, 2001).

\subsection{Identification of virulence factors in isolates included in B. cereus group}

DNA extraction was performed using Wizard Genomic DNA Purification Kit Protocol (Promega, USA), according to manufacturer's instruction. DNA quantification was performed in NanoDrop 2000 (Thermo Scientific Inc., Waltham, MA, USA). The detection of genes $h b l A, h b l B, h b l C$, nheA, nheB and nheC in the selected isolates was performed through PCR targeting mentioned genes on chromosomal DNA in order to verify the potential risk to cause diarrheal disease. Primers and conditions are specified in Table 1.

\section{Statistical analyses}

The quantitative data was initially subjected to Shapiro-Wilk test in order to verify normality and then transformed into log $10 x+1$ and $x+1$ square root and subject again to normality test when normality was not observed. Thus, the data were subjected to non-parametric tests in order to compare the three types of UHT products. Kruskal-Wallis test $(\mathrm{p}<0.05)$ was used initially for multiple comparisons using "pgirmess" package in Software $R^{\circ}$. Mann-Whitney test $(p<0.05)$ was used when a significant statistical difference was observed in the initial analysis in order to compare groups with the highest difference. For the comparison regarding the qualitative data was used the Fisher's exact test $(p<0.05)$. All analyses were performed in Software R', v. 3.3.0.

\section{Results}

Heterotrophic mesophilic microorganisms counts of UHT goat milk, soymilk and dairy beverage of goat milk and soy protein were $<1.0$ to $3.5 \times 10^{4} \mathrm{UFC}^{-\mathrm{ml}^{-1}},<1.0$ to $3.7 \times 10^{4}$ UFC. $\mathrm{ml}^{-1}$ and $<1.0$ to $5.5 \times 10^{4}$ UFC. $\mathrm{ml}^{-1}$, respectively. A significant statistically difference $(\mathrm{p}=0.04)$ was observed in the detection of heterotrophic mesophilic microorganisms counts among samples of goat milk (80\%) and goat milk with soy dairy beverage (100\%).

In this study, the presence of bacteria belonging to $B$. cereus group, that comprises Bacillus anthracis, Bacillus mycoides, Bacillus thuringiensis, Bacillus cereus, Bacillus pseudomycoides, Bacillus weihenstephanensis and Bacillus cytotoxicus, was detected in 28 of $75(37.33 \%)$ samples and 10 of $15(66.66 \%)$ lots evaluated, with $52 \%, 44 \%$ and $16 \%$ of the samples of soymilk, dairy beverage of goat milk and soy protein and goat milk, respectively. 
B. cereus was found in $16 \%$ of UHT goat milk samples and in $52 \%$ samples of dairy beverage of goat milk and soy protein, exhibiting statistical difference $(\mathrm{p}=0,023)$.

High numbers of strains belonging to $B$. cereus group were found to carry genes $h b l C(96.5 \%)$, nheA (79.3\%), nheC (79.3\%), $n h e B(68.9 \%), h b l A(62 \%)$ and $h b l B(48.2 \%)$, as presented in Table 2. Twenty-nine isolates of $B$. cereus were recovered from goat milk $(n=4)$, soymilk $(n=13)$ and dairy beverage of goat milk and soy protein $(n=12)$. From these isolates, all of them (100\%) presented amplification for $h b l A, h b l B$, nheA, nheB and $n h e C$ genes, and $75 \%$ amplified products corresponding to $h b l C$ gene.

Microorganisms from $B$. cereus group isolated from UHT goat milk samples $(n=4), 100 \%$ presented $h b l A, h b l B$, nhe A, nheB and $n$ he $C$ genes while $75 \%$ amplified the fragment corresponding to $h b l C$ gene.

Considering those isolates belonging to B. cereus group obtained from soymilk $(n=13), 100 \%$ amplified $h b l C$ fragment, $76.9 \%$ amplified $n$ he $A, 61.5 \%$ were positive to $n h e C, 53.8 \%$ were positive to $h b l A$ and $n h e B$, while $46.1 \%$ amplified the fragment corresponding to $h b l B$ gene.

Finally, the isolates from $B$. cereus $(n=12)$ obtained from dairy beverage of goat milk and soy protein, all of them (100\%) amplified the fragment corresponding to $h b l C$ gene, while different percentages were observed for nheC, nheA and nheB, hblA and hblB, representing $91.6 \%, 75 \%, 58.3 \%$ and $33.3 \%$, respectively.

C. perfringens was only detected in two samples of UHT soymilk. In UHT goat milk and dairy beverage of goat milk and soy protein this specie was not detected and there was no significant difference among UHT products evaluated $(\mathrm{p}=0,1317)$.

\section{Discussion}

Heterotrophic mesophilic microorganisms count in foods is useful to evaluate the microbiological quality and hygienic conditions of manufacturing. Kondyli et al. (2012) evaluated the microbiological quality of raw goat milk and found values of heterotrophic mesophilic microorganisms ranging from 6.05 to $6.14 \log$ CFU.ml ${ }^{-1}$ and $>10 \times 10^{5}$ CFU.ml ${ }^{-1}$, respectively. Oliveira et al. (2005a) evaluated 16 samples of UHT goat milk and did not isolated heterotrophic mesophilic microorganisms, differing from our study. The results showed here, allows us to suspect that the addition of soy can contribute to increase the presence of microorganisms in dairy products, such as dairy beverage, requiring further studies to prove it.

The Brazilian legislation (Brasil, 2001) establishes the absence of pathogenic microorganisms in UHT goat milk. The presence of high counts of $B$. cereus $\left(>10^{6}\right.$ organisms $\left./ \mathrm{g}^{-1}\right)$ is an indicative of a potential risk for human health (Food and Drug Administration, 2012). Considering the increase in the consumption of UHT products, and from a bacteriological and food safety point of view, the UHT products must be stable at room temperature from four to six months (Pinto et al., 2018).

A significant statistical difference $(\mathrm{p}=0.023)$ was observed among bacteria belonging to $B$. cereus group in goat milk and soymilk. These results highlight the need of improvements during milk and soy obtaining in farms, storage and processing industries in order to improve their microbiological quality.

Table 1. Toxin, gene name, primer, amplicon size (bp), and annealing temperature, according to Guinebretière et al. (2002), used for the detection of virulence factors.

\begin{tabular}{|c|c|c|c|c|}
\hline Toxin & Gene & Primer & $\begin{array}{l}\text { Amplicon Size } \\
\text { (bp) }\end{array}$ & $\begin{array}{l}\text { Annealing temperature } \\
\left({ }^{\circ} \mathrm{C}\right)\end{array}$ \\
\hline \multirow{3}{*}{ Hemolysin BL } & & R 5'-AGAATCTAAATCATGCCACTGC-3' & & \\
\hline & & R 5'-AATATGTCCCAGTACACCCG-3' & & \\
\hline & $h b l C$ & F 5'-GATACYAATGTGGCAACTGC -3' & 740 & 52 \\
\hline \multirow{5}{*}{$\begin{array}{l}\text { Nonhemolytic } \\
\text { enterotoxin }\end{array}$} & & R 5'-ACGAATGTAATTTGAGTCGC -3' & & \\
\hline & nheB & F5'-TTTAGTGGATCTGTACGC -3' & 743 & 48 \\
\hline & & R 5'-TTAATGTTCGTTAATCCTGC -3' & & \\
\hline & nheC & F 5'-TGGATTCCAAGATGTAACG -3' & 683 & 54 \\
\hline & & R 5'-ATTACGACTTCTGCTTGTGC -3' & & \\
\hline
\end{tabular}

Table 2. Prevalence of $h b l A, h b l B, h b l C$, nheA, nheB and $n h e C$ in 29 isolates.

\begin{tabular}{|c|c|c|c|c|c|c|c|}
\hline \multirow{2}{*}{ Product } & \multirow{2}{*}{$\begin{array}{l}\text { Number of } \\
\text { isolates }\end{array}$} & \multicolumn{6}{|c|}{ Genes } \\
\hline & & hblA & $h b l B$ & $h b l C$ & nheA & nheB & nheC \\
\hline UHT goat milk & 4 & $4(100 \%)$ & $4(100 \%)$ & $3(75 \%)$ & $4(100 \%)$ & $4(100 \%)$ & $4(100 \%)$ \\
\hline UHT soymilk & 13 & $7(53.8 \%)$ & $6(46.1 \%)$ & $13(100 \%)$ & $10(76.9 \%)$ & $7(53.8 \%)$ & $8(61.5 \%)$ \\
\hline $\begin{array}{l}\text { UHT dairy beverage of goat } \\
\text { milk and soy protein }\end{array}$ & 12 & $7(58.3 \%)$ & $4(33.3 \%)$ & $12(100 \%)$ & $9(75 \%)$ & $9(75 \%)$ & $11(91.6 \%)$ \\
\hline Total & 29 & $18(62 \%)$ & $14(48.2 \%)$ & $28(96.5 \%)$ & $23(79.3 \%)$ & $20(68.9 \%)$ & $23(79.3 \%)$ \\
\hline
\end{tabular}


Nakajima et al. (2010) report that the consumption of soymilk is done mostly by people concerned about their health, aiming the substitution of cow milk, reduction of hypercholesterolemia and the risk of osteoporosis and diabetes. The mean age of the interviewed consumers in the cited study was 32.5 years, reaching the age of 78 years, considered more susceptible to opportunistic infections (Nakajima et al., 2010).

Detection of nheA, nheB, nheC, hblA, hblB and $h b l C$ genes is useful to verify the potential to cause diarrheal illness in strains belonging to B. cereus group (Ehling-Schulz et al., 2004). According to Lee et al. (2017), from $90 \%$ to $100 \%$ from B. cereus group isolated from food samples can carry the $h b l A C D$ and nhe $A B C$ genes. Chaves et al. (2011) evaluated 97 strains of $B$. cereus sensu stricto collected over three years and observed that $84.5 \%$ and $62.9 \%$ of the strains were positive for NHE and HBL complex, respectively.

A high number of isolates containing toxigenic genes were found in this study, highlighting the potential for production of hemolytic and nonhemolytic toxins. Amplicons for $h b l C$ gene were detected in $100 \%$ of the isolates obtained from dairy beverage of goat milk and soy protein. The members of B. cereus group are commonly present contaminants of fresh and heat-treated milk (Bartoszewicz et al., 2008). In a study performed by Bartoszewicz et al. (2008), the authors established a prevalence of 80 and $55 \%$ for nheA and hblA in isolates obtained from dairy farms and dairies in Poland.

Zhou et al. (2008) evaluated 100 isolates obtained from samples of pasteurized whole milk sold in China. These authors revealed that the enterotoxin genes $h b l \mathrm{~A}, h b l \mathrm{C}, h b l \mathrm{D}$, nheA, $n h e \mathrm{~B}$ and $n h e \mathrm{C}$ occurred in $\mathrm{B}$. cereus isolates with frequencies of $37.0 \%, 66.3 \%, 71.7 \%, 71.7 \%, 62.0 \%$ and $71.7 \%$, respectively.

There are few studies available in literature regarding the presence of toxigenic $B$. cereus group in soy products. Yim et al. (2015) evaluated the toxigenic profile of B. cereus sensu stricto in Korean soybean fermented products, detecting $h b l A C D$ and nhe $A B C$ genes in $34.5 \%$ and $98.9 \%$ of the strains, respectively. Park et al. (2016) reported high number of strains positive for diarrheal toxin genes in Doenjang, a Korean fermented soybean past, demonstrating the importance of potentially pathogenic strains in soy products.

In the work of Lee et al. (2017), only 8.6-23\% of the isolates containing $\mathrm{hbl}$ encoded the enterotoxin HBL. The production of hemolytic and nonhemolytic enterotoxins is complex and involves transcriptional regulator proteins, posttranscriptional and posttranslational regulatory mechanisms and environmental conditions (Jeßberger et al., 2015).

The genes nhe $A, n h e B$ and $n h e C$ show more toxicity for the epithelial cells. In vitro tests, under high concentrations of the toxin nhe, the target cells suffer quick cellular apoptosis, concomitant with a necrotic condition (Liu et al., 2017). The genes of the complex HBL are also associated with a strong degenerative effect on the cell membrane (Berthold-Pluta et al., 2015), which shows the degree of pathogenicity of the strains of $B$. cereus group.

Clostridium perfringens strains are widely prevalent in feces of lactating cows and play an important role in diarrheal diseases
(Food and Drug Administration, 2012). Meat and poultry dishes are the most important source of $C$. perfringens infection for humans during foodborne outbreaks; however, an outbreak due its presence in milk was already reported (Bennett et al., 2013).

C. perfringens type A food poisoning occurs due to the production of the enterotoxin after the ingestion of $>10^{7}$ cells of C. perfringens. Contaminated food is almost always heat-treated which kills competing bacteria while spores survive and is the dominating, as shown in this study. Besides $C$. perfringens detection in this study, its presence cannot be considered as a risk for foodborne disease if adequate conditions of storage are observed. Complementary studies are required to verify the presence of $C$. perfringens virulence factors, due to its ability to cause foodborne disease.

Obtained data indicate the unsatisfactory microbiological quality of the analyzed UHT products, suggesting the implementation of a rigorous quality assurance system for food safety using Good Manufacturing Practices (GMP) and Analysis and Critical Control Point (HACCP) (Cusato et al., 2013; Oliveira et al., 2016b). Using this strategy, it is possible to reduce the prevalence of foodborne diseases (Carrascosa et al., 2016).

Knowing that $B$. cereus can be present in raw, pasteurized and UHT milk (Vidal-Martins et al., 2006), spores of this microorganism are able to resist to heat treatments and that enterotoxigenic strains were detected in this study, improvements in milking and storage conditions should be implemented.

\section{Conclusion}

The observed microbiological quality of UHT goat milk, soymilk and dairy beverage of goat milk and soy protein evaluated was unsatisfactory. Pathogenic microorganisms such as $C$. perfringens and potentially diarrheagenic strains belonging to $B$. cereus group were detected, highlighting the needs of improvements on adoption of hygienic practices during obtaining, manufacturing and storage of these products in order to improve food safety, mainly because they are consumed by elderly people and consumer suffering with allergies, being a potential hazard for this population.

\section{References}

American Public Health Association - APHA. (2001). Compendium of methods for the microbiological examination of foods (4th ed., Vol. 1, p. 676). Washington: American Public Health Association.

Bartoszewicz, M., Hansen, B. M., \& Swiecicka, I. (2008). The members of the Bacillus cereus group are commonly present in fresh and heat-treated milk. Food Microbiology, 25(4), 588-596. http://dx.doi. org/10.1016/j.fm.2008.02.001. PMid:18456114.

Beltrán, M. C., Morari-Pirlog, A., Quintanilla, P., Escriche, I., \& Molina, M. P. (2018). Influence of enrofloxacin on the coagulation time and the quality parameters of goat's milk yoghurt. International Journal of Dairy Technology, 71(1), 105-111. http://dx.doi.org/10.1111/14710307.12388.

Bennett, S. D., Walsh, K. A., \& Gould, L. H. (2013). Foodborne disease outbreaks caused by Bacillus cereus, Clostridium perfringens, and Staphylococcus aureus - United States, 1998-2008. Clinical Infectious Diseases, 57(3), 425-433. http://dx.doi.org/10.1093/cid/cit244. PMid:23592829. 
Berthold-Pluta A, Pluta A, Garbowska M. The effect of selected factors on the survival of Bacillus cereus in the human gastrointestinal tract. Microbial pathogenesis. 2015; 82:7-14.

Blum JES, Ramoni EO, Balbi ME. Extract of Preparing Soluble (Milk) From Sunflower Seeds Germinated (Helianthus Annus L., Asteraceae) and Evaluation of Their Nutritional Composition. Visão Acadêmica, 2016; 17(1), 81-95.

Brasil. Ministério da Saúde. (2001, January 2). Regulamento Técnico sobre os Padrões Microbiologicos para Alimentos (Resolução n ${ }^{\circ}$, de 2 de janeiro de 2001). Diário Oficial [da] República Federativa do Brasil, Brasilia, seção 1.

Cappato, L. P., Ferreira, M. V. S., Moraes, J., Pires, R. P., Rocha, R. S., Silva, R., Neto, R. P. C., Tavares, M. I. B., Freitas, M. Q., Rodrigues, F. N., Calado, V. M. A., Raices, R. S. L., Silva, M. C., \& Cruz, A. G. (2018b). Whey acerola-flavoured drink submitted Ohmic Heating: Bioactive compounds, antioxidant capacity, thermal behavior, water mobility, fatty acid profile and volatile compounds. Food Chemistry, 263, 81-88. http://dx.doi.org/10.1016/j.foodchem.2018.04.115. PMid:29784332.

Cappato, L. P., Ferreira, M. V. S., Pires, R. P., Cavalcanti, R. N., Bisaggio, R. C., Freitas, M. Q., Silva, M. C., \& Cruz, A. G. (2018a). Whey acerolaflavoured drink submitted ohmic heating processing: Is there an optimal combination of the operational parameters? Food Chemistry, 245, 22-28. http://dx.doi.org/10.1016/j.foodchem.2017.10.019. PMid:29287363.

Carrascosa, C., Millán, R., Saavedra, P., Jaber, J. R., Raposo, A., \& Sanjuán, E. (2016). Identification of the risk factors associated with cheese production to implement the hazard analysis and critical control points (HACCP) system on cheese farms. Journal of Dairy Science, 99(4), 2606-2616. http://dx.doi.org/10.3168/jds.2015-10301. PMid:26851842.

Chaves, J. Q., Pires, E. S., \& Vivoni, A. M. (2011). Genetic diversity, antimicrobial resistance and toxigenic profiles of Bacillus cereus isolated from food in Brazil over three decades. International Journal of Food Microbiology, 147(1), 12-16. http://dx.doi.org/10.1016/j. ijfoodmicro.2011.02.029. PMid:21440319.

Clark, S., \& Mora García, M. B. (2017). A 100-year review: Advances in goat milk research. Journal of Dairy Science, 100(12), 10026-10044. http://dx.doi.org/10.3168/jds.2017-13287. PMid:29153153.

Cusato, S., Gameiro, A. H., Corassin, C. H., Sant'Ana, A. S., Cruz, A. G., Faria, J. D. A. F., \& de Oliveira, C. A. F. (2013). Food safety systems in a small dairy factory: Implementation, major challenges, and assessment of systems' performances. Foodborne Pathogens and Disease, 10(1), 6-12. http://dx.doi.org/10.1089/fpd.2012.1286. PMid:23153286.

Ehling-Schulz, M., Guinebretiere, M. H., Monthán, A., Berge, O., Fricker, M., \& Svensson, B. (2004). Toxin gene profiling of enterotoxic and emetic Bacillus cereus. FEMS Microbiology Letters, 260(2), 232-240. http://dx.doi.org/10.1111/j.1574-6968.2006.00320.x. PMid:16842349.

Eijlander, R. T., Van Hekezen, R., Bienvenue, A., Girard, V., Hoornstra, E., Johnson, N. B., Meyer, R., Wagendorp, A., Walker, D., \& WellsBennik, M. H. (2019). Spores in dairy-new insights in detection, enumeration and risk assessment. International Journal of Dairy Technology, 72(2), 303-315. http://dx.doi.org/10.1111/1471-0307.12586.

Fangmeier, M., Kemerich, G. T., Machado, B. L., Maciel, M. J., \& Souza, C. F. V. D. (2019). Effects of cow, goat, and buffalo milk on the characteristics of cream cheese with whey retention. Food Science and Technology, 39(Suppl. 1), 122-128.

Ferreira, M. V. S., Cappato, L. P., Silva, R., Rocha, R. S., Guimarães, J. T., Balthazar, C. F., Esmerino, E. A., Freitas, M. Q., Rodrigues, F. N., Granato, D., Neto, R. P. C., Tavares, M. I. B., Silva, P. H. F., Raices,
R. S. L., Silva, M. C., \& Cruz, A. G. (2019a). Ohmic Heating for processing of whey-raspberry flavored beverage. Food Chemistry, 297, 125018. http://dx.doi.org/10.1016/j.foodchem.2019.125018. PMid:31253265.

Ferreira, M. V. S., Cappato, L. P., Silva, R., Rocha, R. S., Neto, R. P., Tavares, M. I. B., Esmerino, E. A., Freitas, M. Q., Bissagio, R. C., Ranadheera, S., Raices, R. S., Silva, M. C., \& Cruz, A. G. (2019b). Processing raspberry-flavored whey drink using ohmic heating: Physical, thermal and microstructural considerations. Food Research International, 123, 20-26. http://dx.doi.org/10.1016/j. foodres.2019.04.045. PMid:31284969.

Fonseca, C. R., Bordin, K., Fernandes, A. M., Rodrigues, C. E. C., Corassin, C. H., Cruz, A. G., \& Oliveira, C. A. F. (2013). Storage of refrigerated raw goat milk affecting the quality of whole milk powder. Journal of Dairy Science, 96(7), 4716-4724. http://dx.doi. org/10.3168/jds.2012-6120. PMid:23664351.

Food and Drug Administration - FDA. (2012). The Bad Bug Book, Foodborne Pathogenic Microorganisms and Natural Toxins (2nd ed.). Maryland: FDA. Retrieved from: https://www.fda.gov/downloads/ Food/FoodborneIllnessContaminants/UCM297627.pdf>

Garcia, M. C., Elias, T. M,, Ribeiro, K. D. O., Soares Júnior, M. S., \& Caliari, M. (2018). Microbiological and physicochemical profiles of the sour cassava starch and bagasse obtained from cassava agroindustry. Food Science and Technology, 39(4), 803-809.

Guinebretière, M. H., Broussolle, V., \& Nguyen-The, C. (2002). Enterotoxigenic profiles of food-poisoning and food-borne Bacillus cereus strains. Journal of Clinical Microbiology, 40(8), 3053-3056.

Jeßberger, N., Krey, V. M., Rademacher, C., Böhm, M. E., Mohr, A. K., Ehling-Schulz, M., Scherer, S., \& Märtlbauer, E. (2015). From genome to toxicity: a combinatory approach highlights the complexity of enterotoxin production in Bacillus cereus. Frontiers in Microbiology, 6, 560. http://dx.doi.org/10.3389/fmicb.2015.00560. PMid:26113843.

Jindal, S., \& Anand, S. (2018). Comparison of adhesion characteristics of common dairy sporeformers and their spores on unmodified and modified stainless steel contact surfaces. Journal of Dairy Science, 101(7), 5799-5808. http://dx.doi.org/10.3168/jds.2017-14179. PMid:29605327.

Karaçali, R., Özdemir, N., \& Çon, A. H. (2018). Aromatic and functional aspects of kefir produced using soya milk and Bifidobacterium species. International Journal of Dairy Technology, 71(4), 921-933. http://dx.doi.org/10.1111/1471-0307.12537.

Kmiha, S., Aouadhi, C., Klibi, A., Jouini, A., Béjaoui, A., Mejri, S., \& Maaroufi, A. (2017). Seasonal and regional occurrence of heat-resistant spore-forming bacteria in the course of ultra-high temperature milk production in Tunisia. Journal of Dairy Science, 100(8), 6090-6099. http://dx.doi.org/10.3168/jds.2016-11616. PMid:28571988.

Kondyli, E., Svarnas, C., Samelis, J., \& Katsiari, M. C. (2012). Chemical composition and microbiological quality of ewe and goat milk of native greek breeds. Small Ruminant Research, 103(2-3), 194-199. http://dx.doi.org/10.1016/j.smallrumres.2011.09.043.

Kuchtík, J., Králicková, S., Zapletal, D., Weglarzy, K., Sustová, K., \& Skrzyzala, I. (2015). Changes in physico-chemical characteristics, somatic cell count and fatty acid profile of Brown Short-haired goat milk during lactation. Animal Science Papers and Reports, 33(1), 71-83.

Kwok, K. C., Liang, H. H., \& Niranjan, K. (2002). Optimizing conditions for thermal processes of soy milk. Journal of Agricultural and Food Chemistry, 50(17), 4834-4838. http://dx.doi.org/10.1021/jf020182b. PMid:12166968.

Lee, N., Kim, M. D., Chang, H. J., Choi, S. W., \& Chung, H. S. (2017). Genetic diversity, antimicrobial resistance, toxin gene profiles, and toxin production ability of Bacillus cereus isolates from doenjang, a 
Koean fermented soybean paste. Journal of Food Safety, 37(4), 1-7. http://dx.doi.org/10.1111/jfs.12363.

Liu, X., Ding, S., Shi, P., Dietrich, R., Märtlbauer, E., \& Zhu, K. (2017). Non-hemolytic enterotoxin of Bacillus cereus induces apoptosis in Vero cells. Cellular Microbiology, 19(4), e12684. http://dx.doi. org/10.1111/cmi.12684. PMid:27762484.

Mituniewicz-Małek, A., Zielińska, D., \& Ziarno, M. (2019). Probiotic monocultures in fermented goat milk beverages-sensory quality of final product. International Journal of Dairy Technology, 72(2), 240-247. http://dx.doi.org/10.1111/1471-0307.12576.

Mossel, D. A. A., Koopman, M. J., \& Jongerius, E. (1967). Enumeration of Bacillus cereus in foods. Applied Microbiology, 15(3), 650-653. http://dx.doi.org/10.1128/AEM.15.3.650-653.1967. PMid:4291956.

Nakajima, V. M., Oliveira, C. G., Costa, A. G. V., Paixão, M. P. C., Arruda, A. C., \& Minim, V. P. R. (2010). Habits and motivations for the consumption or not consumption of water soluble soy extract. Alim. Nutr. Araraquara., 21(4), 633-642.

Oliveira, C. A. F., Cruz, A. G., Tavolaro, P., \& Corassin, C. H. (2016a). Food Safety: Good Manufacturing Practices (GMP), Sanitation Standard Operating Procedures (SSOP), Hazard Analysis and Critical Control Point (HACCP). In J. Barros-Velázquez (pp. 129-139). Antimicrobial Food. London: Packaging Academic Press. http:// dx.doi.org/10.1016/B978-0-12-800723-5.00010-3.

Oliveira, R. B., Margalho, L. P., Nascimento, J. S., Costa, L. E., Portela, J. B., Cruz, A. G., \& Sant'Ana, A. S. (2016b). Processed cheese contamination by spore-forming bacteria: A review of sources, routes, fate during processing and control. Trends in Food Science \& Technology, 57, 11-19. http://dx.doi.org/10.1016/j.tifs.2016.09.008.

Oliveira, M. A., Fávaro, R. M. D., Okada, M. M., Abe, L. T., \& Iha, M. H. (2005). Physicochemical and microbiological quality of frozen pasteurized goat whole milk and of Ultra-High Temperature milk commercialized in the region of Ribeirão Preto - SP. Revista do Instituto Adolfo Lutz, 64(1), 104-109.

Oliveira, R. B., Baptista, R. C., Chincha, A. A., Conceição, D. A., Nascimento, J. S., Costa, L. E., Cruz, A. G., \& Sant'Ana, A. S. (2018). Thermal inactivation kinetics of Paenibacillus sanguinis 2301083PRC and Clostridium sporogenes JCM1416MGA in full and low fat "requeijão cremoso". Food Control, 84, 395-402. http:// dx.doi.org/10.1016/j.foodcont.2017.08.030.

Park, K. M., Kim, H. J., Jeong, M. C., \& Koo, M. (2016). Occurrence of toxigenic Bacillus cereus and Bacillus thuringiensis in Doenjang, a Korean fermented soybean past. Journal of Food Protection, 79(4), 605-612. http://dx.doi.org/10.4315/0362-028X.JFP-15-416. PMid:27052865.

Pinto, C. L., Souza, L. V., Meloni, V. A., Batista, C. S., Silva, R., Martins, E. M., Cruz, A. G., \& Martins, M. L. (2018). Microbiological quality of Brazilian UHT milk: Identification and spoilage potential of spore-forming bacteria. International Journal of Dairy Technology, 71(1), 20-26. http://dx.doi.org/10.1111/1471-0307.12339.
Pradeep Prasanna, P. H., \& Charalampopoulos, D. (2019). Encapsulation in an alginate-goats' milk-inulin matrix improves survival of probiotic Bifidobacterium in simulated gastrointestinal conditions and goats' milk yoghurt. International Journal of Dairy Technology, 72(1), 132-141. http://dx.doi.org/10.1111/1471-0307.12568.

Quigley, L., O’sullivan, O., Stanton, C., Beresford, T. P., Ross, R. P., Fitzgerald, G. F., \& Cotter, P. D. (2013). The complex microbiota of raw milk. FEMS Microbiology Reviews, 37(5), 664-698. http:// dx.doi.org/10.1111/1574-6976.12030. PMid:23808865.

Reindl, A., Dzieciol, M., Hein, I., Wagner, M., \& Zangerl, P. (2014). Enumeration of clostridia in goat milk using an optimized membrane filtration technique. Journal of Dairy Science, 97(10), 6036-6045. http://dx.doi.org/10.3168/jds.2014-8218. PMid:25129496.

Rezende, N. C. M., Júnior, O. D. R., \& Amaral, L. A. (2015). Ocorrência de bactérias do grupo do Bacillus cereus em leite UHT integral (ultra-high-temperature). Revista Brasileira de Ciência Veterinária, 7(3), 162-166. http://dx.doi.org/10.4322/rbcv.2015.205.

Ryang, J. H., Kim, N. H., Lee, B. S., Kim, C. T., \& Rhee, M. S. (2016). Destruction of Bacillus cereus spores in a thick soy bean paste (doenjang) by continuous ohmic heating with five sequential electrodes. Letters in Applied Microbiology, 63(1), 66-73. http:// dx.doi.org/10.1111/lam.12588. PMid:27214292.

Schoken-Iturrino, R. P., Nader Filho, A., \& Dimenstein, A. R. (1996). Ocorrência de bactérias esporuladas dos gêneros Bacillus e Clostridium em amostras de leite longa vida. Higiene Alimentar, 10(42), 25-27.

Stadhouders, J. (1992). The enumeration of spores and vegetative cells of Bacillus cereus. Bulletin of the International Dairy Federation, 275, 15-18.

Vidal, A. M. C., Rossi, O. D. Jr, Abreu, I. L. D., Bürger, K. P., Cardoso, M. V., Gonçalves, A. C. S., Rossi, G. A. M., \& D’Abreu, L. F. (2016). Detection of Bacillus cereus isolated during ultra high temperature milk production flowchart through random amplified polymorphic DNA polymerase chain reaction. Ciência Rural, 46(2), 286-292. http://dx.doi.org/10.1590/0103-8478cr20141539.

Vidal-Martins, A. M. C., Júnior, O. D. R., Bürger, K. P., Cardozo, M. V., Salloti, B. M., \& Cortez, A. L. L. (2006). Bacillus cereus enterotoxigênicos em diferentes fases do processamento de leite UAT. Revista Brasileira de Ciência Veterinária, 13(1), 32-36. http:// dx.doi.org/10.4322/rbcv.2014.262.

Yim, J. H., Kim, K. Y., Chon, J. W., Kim, D. H., Kim, H. S., Choi, D. S., Choi, I. S., \& Seo, K. H. (2015). Incidence, antibiotic susceptibility, and toxin profiles of Bacillus cereus sensu lato isolated from Korean fermented soybean products. Journal of Food Science, 80(6), 12661270. http://dx.doi.org/10.1111/1750-3841.12872. PMid:25950845.

Zhou, G., Liu, H., He, J., Yuan, Y., \& Yuan, Z. (2008). The occurrence of Bacillus cereus, B. thuringiensis and B. mycoides in Chinese pasteurized full fat milk. International Journal of Food Microbiology, 121(2), 195-200. http://dx.doi.org/10.1016/j.ijfoodmicro.2007.11.028. PMid:18077041. 